\title{
The River Management Modelling For Ecology
}

\author{
Havva Ulgen Yenil ${ }^{1}$, Tolga Taner ${ }^{2, *}$ \\ ${ }^{1}$ Department of Park and Garden Plants, Vocational School of Technical Sciences, Aksaray University, Aksaray, Turkey \\ ${ }^{2}$ Department of Motor Vehicles and Transportation, Vocational School of Technical Sciences, Aksaray University, Aksaray, Turkey \\ *Corresponding author: tolgataner@aksaray.edu.tr
}

Received June 30, 2014; Revised July 17, 2014; Accepted July 21, 2014

\begin{abstract}
In this study, the river management modelling was analysed based on ecology at a critical approach. Our laws and legal arrangements that are one of the significant water resources, affect our river management. This modelling obtains these laws and legal arrangement's effective and problems. These problems create to ensure ecological sustainability. So, we used SWOT analysis for the existing laws and institutions. Also we discussed the methodological approaches that the protection of nature is important taking a decision and runtime for the place of the institutional structuring. The river management modelling develops for our country from taking the European Water Framework Directive's knowledge. In addition, to ensure the monitoring of ecological criteria which constitutes important basis for planning of watershed, vegetation, aquatic wildlife and coastal land use systematic recommendations have been created. Development of the river management and application can be settled in our country. The river management is also important for our energy about natural life and transportation.
\end{abstract}

Keywords: river management, ecology, energy, SWOT analysis, water

Cite This Article: Havva Ulgen Yenil, and Tolga Taner, "The River Management Modelling For Ecology." American Journal of Water Resources, vol. 2, no. 3 (2014): 71-73. doi: 10.12691/ajwr-2-3-3.

\section{Introduction}

In the world, the environmental problem is the degradation and depletion's danger of water resources, now. The management of water resources are an important requirement, but they are shaped with the legal framework of each country. In recent years, due to our country recognizes European Water Framework Directive. Ecological Watershed Planning is done [1].

Today, as a result of the unconscious of nature we have some problems, such as pollution, depletion of natural resources, biodiversity and habitat destructions. In the world, the environmental problem is the degradation and depletion's danger of water resources. The management of water resources are an important requirement, but they shape the legal framework of each country [2].

Ecological interaction of items consider that are associated with natural resources, revealed effects on natural resources, positive and negative effects of internalexternal dynamics and processes [3].

\section{Material and Methods}

In this study, we analysed the river management modelling based on ecology at a critical approach. Our laws and legal arrangements affect our river management that are one of the significant water resources (Figure 1 and Figure 2). It can be obtained these laws and legal arrangement that how effective or what kind of problems are created to ensure ecological sustainability. We applied
SWOT analysis for the river management modelling. So, SWOT analysis was used.

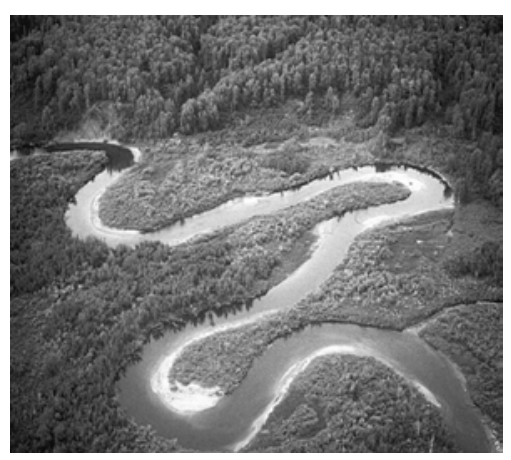

Figure 1. Modelling river

Modelling river can be seen in Figure 1. Modelling river can flow without irritation to the environment.

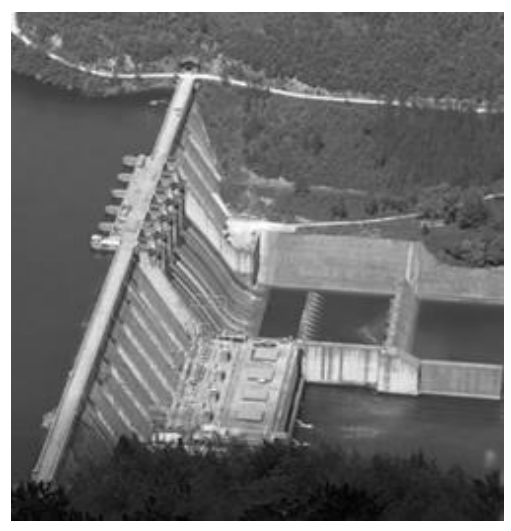

Figure 2. Modelling hydroelectric plant 
Also we can see the modelling hydroelectric plant in Figure 2. A modelling hydroelectric plant is made not giving harming to the ecosystem.

\section{Environmental Parameters/Disciplines}

This modelling will be very useful as local and regional for the corporate perspective, combining the institutional capacity in an integrated and coherent manner. Each river watershed management system must be created according to the national vision and policy [5].

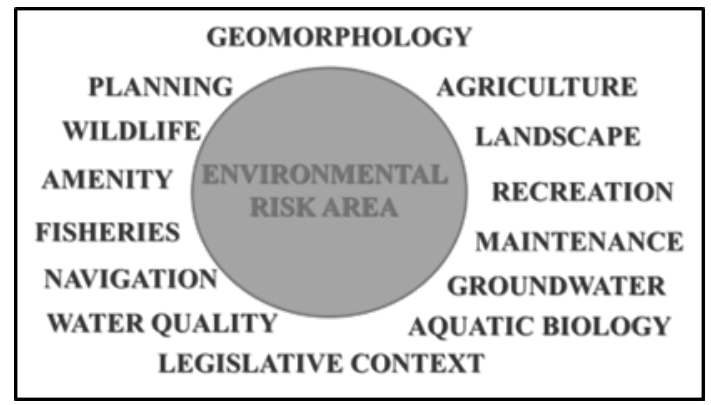

Figure 3. Diagram of the environmental parameters/ disciplines [6]

Ecological river planning and management activity' environmental parameters and disciplines can take place based on the European Water Framework Directive that is given in Figure 3 [6].

\section{SWOT Analysis of Laws for the River}

SWOT analysis can explain in positive and negative ways. These are Strengths - Opportunities and Weaknesses - Threats as shown;

Strengths - Opportunities; There are opportunities for all kinds of private and public investment in rivers. Flood planning framework is handled well. Prohibitions are clear and revealing. The presences of rivers are intense and related institutional equipment that is sufficient in Turkey. New regulations are necessity with the European Water Framework Directive.

Weaknesses - Threats; they are not based on ecology that the lack of communication between institutions, criminal proceedings and emergency plans in practice. A gap in laws including each other and operability of the control mechanism is inadequate [2].

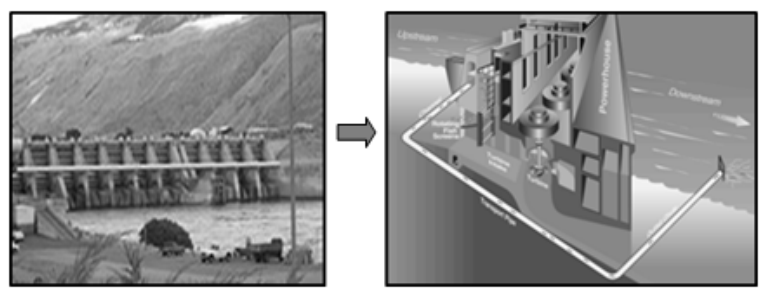

Figure 4. Rocky Reach Dam in U.S. state of Chelan / Douglas counties, Washington and Army Corps of Engineers illustration of juvenile fish bypass (A sample)

A sample of river modelling is seen in Figure 4 about Rocky Reach Dam in U.S. state of Chelan / Douglas counties, Washington and Army Corps of Engineers illustration of juvenile fish bypass. Also it explained and studied the reservoir of Rocky Reach Dam $[7,8]$.
In Figure 4, Rocky Reach Dam is a reservoir that is using for the energy and ecosystem. When gaining the energy in efficiently, fish and the other living things are saved by the channel that is a transport pipe. So, energy is produced and the extinction of live animals living is prevented in the lake, without disturbing the ecosystem.

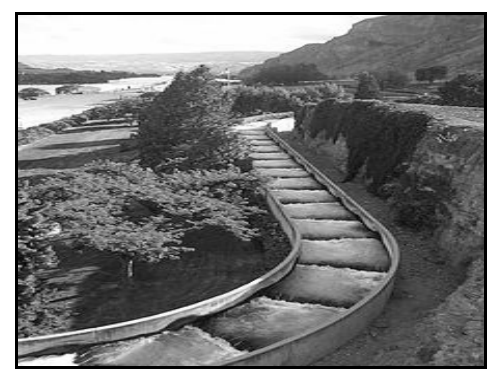

Figure 5. Salmon ladder below dam (Rocky Reach Dam)

Also, the salmon ladder below dam can be seen (Rocky Reach Dam) in Figure 5. This salmon ladder made in gradual way that is using with the irrigation canal for the irrigation area.

In Turkey, river watershed ecological improvement plan can be seen in Figure 6. Firstly, DSI (The State of Hydraulic Works in Turkey) determine the local watershed management assembly with economical and implementation then public data bank, university and local people with contributions create the river watershed ecological improvement plan [9].

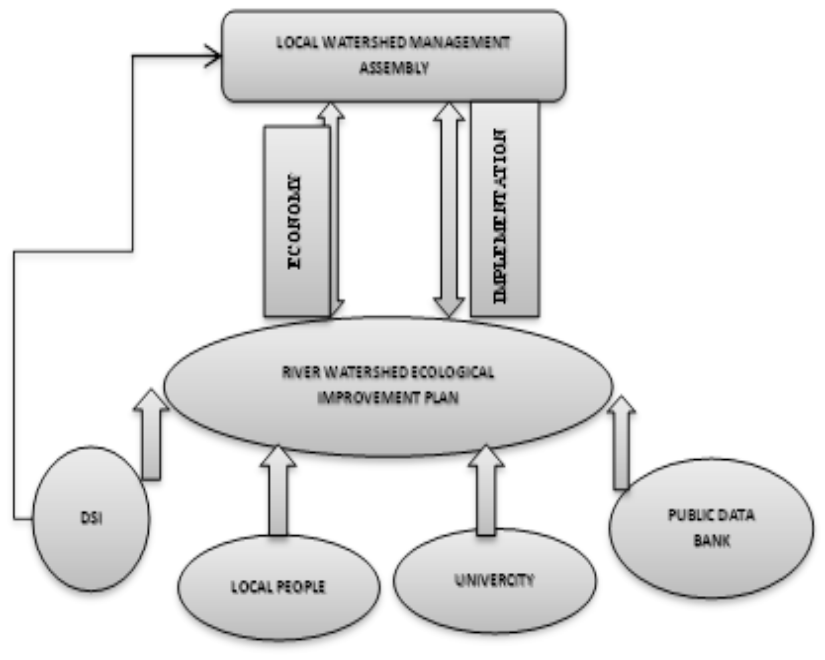

Figure 6. River watershed ecological improvement plan in Turkey [9]

When look at the Figure 6, it can be seen river watershed ecological improvement plan in Turkey that is a focus notion for the planning river model.

\section{Conclusion and Discuss}

As a result, the establishment of institutional structures built an integrated management plan should be implemented. Ecological implementation of watershed management philosophy is based on ecology for our country by the European Water Framework modelling is necessary to improve river management $[9,10]$. Also we can show the alternative river management strategies in the Hungarian reaches of the Tisza River Basin [11]. These models are able to predict hydrological and 
geomorphological forms, though, has been replicated to the stream biota events, long-term data scarcity assessment of metapopulation dynamics model, which requires new means of monitoring data [12].

In addition, watershed planning has been created vegetation, wildlife and water systematic recommendations for the use of coastal land. Ecological criteria are required for monitoring. The river modelling can be developed in our country. The river management is also more important for the transportation and energy.

\section{References}

[1] Wijk, F. J., Haye, M. A. A., Hehenkamps, M. J., Velde, I. A., Bruin, E. F. L. M., Schelleman, F. J. M., Su çerçeve direktifinin Türkiye'de uygulanması, Uygulama El Kitabı, Istanbul, Turkey, 2003.

[2] Yenil, Ü., Ülkemizde akarsuların yönetiminde yasal ve yönetsel durum, Ankara Üniversitesi, Ankara, Turkey, 2009.

[3] Taş, E., Essentiality of integrated water resources management for sustainable water management, 3. Uluslararas1 Bursa Su Kongresi Bildiriler Kitabı, Bursa, Turkey, 2013.

[4] Pekin, U., Kentsel akarsu koridorlarının geliştirilmesi ve Ankara Çayı kavramsal yeşil yol planı, Doktora Tezi, Ankara Üniversitesi, Ankara, Turkey, 2007.
[5] Küçükali, U., Atabay, S., Su havzaları planlamasinda ekometodolojik bir yaklaşım-Marmara Bölgesinden Örnekler, 3. Uluslararası Bursa Su Kongresi Bildiriler Kitabı, Bursa, Turkey, 2013.

[6] Gardiner, J., River projects and conservation, John Wiley \& Sons Publications, England, 1994.

[7] Steig, T. W. and Johnston, S. V., VI. Fish and plankton behaviour and reaction: Monitoring fish movement patterns in a reservoir using horizontally scanning split-beam techniques, ICES Journal of Marine Science (53). 1996, 435-441.

[8] Steig, T. W., The use of acoustics tags to monitor the movement of juvenile salmonids approaching a dam on the Columbia River, 15th International Symposium on Biotelemetry, Juneau, Alaska, USA, 1999.

[9] Yenil, Ü., Zir deresi ekolojik iyileştirme ve peyzaj yönetim modeli, Doktora Tezi, Ankara Üniversitesi, Ankara, Turkey, 2010.

[10] Wolk, M., Hirschfeld, J. Dehnhardt, A., Schmidt, G. Bohn, C., Liersch, S., Gassman, P.W., Integrated ecological-economic modelling of water pollution abatement management options in the Upper Ems River Basin, Ecological Economics (66) 1. 2008, 66-76.

[11] Sendzimir, J., Magnuszewski, P., Flachner, Z., Balogh, P., Molnar, G., Sarvari, A. and Nagy, Z., Assessing the Resilience of a River Management Regime: Informal Learning in a Shadow Network in the Tisza River Basin, Ecology and Society (13) 1. 2008.

[12] Freeman, M. C., and et. al, Linking river management to species conservation using dynamic landscape-scale models, River Research and Applications, 2012. 